\title{
Pengaruh Pembiayaan Murabahah dan MudharabahTerhadap Perkembangan Usaha Kecil Nasabah BMT Mu'amalah Syari'ah Tebuireng Jombang
}

\author{
Indah Parwati \\ Universitas Hasyim Asy'ari \\ indahslalu28@gmail.com
}

\begin{abstract}
This study aimed to analyze the influence of murabahah financing and mudharabah in BMT Mu'amalah Syari'ah Tebuireng Jombang on customer's micro business development. This study used quantitative methods. The datas were analyed using simple linear regression analysis to know the influence between the independent variables and dependent variabels. The research population were 30 murabahah financing's customers and 19 customers of mudharabah financing. Thus, the entire population of murabahah and mudharabah financing customers were used as the research sample. Data collection techniques used questionnaires and documentation to obtain data on the number of customers and about the development of small business. The results showed that murabahahfinancing and mudharabah had a significant positive effect on the development of small business customers BMT Mu'amalah Syari'ah Tebuireng Jombang.
\end{abstract}

Keywords:Murabahah, Financing, Mudharabah,Micro Business

\section{A. PENDAHULUAN}

Pelaku usaha kecil dalam pengembangan usahanya sering kali berhubungan dengan lembaga keuangan dalam hal permodalan. Munculnya lembaga keuangan syariah non bank yang fokus pada pembiayaan usaha kecil seperti koperasi syariah, dan Baitul Mal atTamwil (BMT) mempunyai konstribusi dalam mendistribusikan permodalan bagi Usaha Mikro Kecil dan Menengah (UMKM).

Baitul Mal at-Tamwil (BMT) sendiri merupakan lembaga swadaya masyarakat, dalam artian didirikan dan dikembangkan oleh masyarakat. Pada awal pendiriannya, biasanya dilakukan dengan menggunakan sumber daya, termasuk dana atau modal dari masyarakat sendiri. Sejak awal berdirinya, BMT dirancang sebagai lembaga ekonomi, sehingga dapat disebut bahwa BMT merupakan suatu lembaga ekonomi rakyat, yang secara konsepsi dan secara nyata memang lebih fokus kepada masyarakat. BMT berupaya membantu pengembangan usaha mikro dan usaha kecil, terutama bantuan permodalan. Untuk melancarkan usaha membantu permodalan tersebut, maka BMT juga berupaya menghimpun dana, terutama berasal dari masyarakat lokal di sekitarnya (Amalia, 2009 : 82).

Sesuai dengan namanya, BMT melaksanakan dua jenis kegiatan yaitu Bait al-Mal dan Bait at-Tamwil. Sebagai Bait al-Mal, BMT menerima zakat, infak dan sedekah serta menyalurkan sesuai dengan peraturan dan amanahnya. Sedangkan Bait at-Tamwil, BMT bergiat untuk mengembangkan usaha-usaha produktif dan investasi dalam meningkatkan kualitas kegiatan pengusaha kecil dengan mendorong kegiatan menabung dan menunjang pembiayaan ekonomi (Amalia, 2009:85). Namun realitanya kebanyakan BMT lebih mengedepankan kegiatan Bait at-Tamwil dan menihilkan kegiatan Bait al-Mal. 
Lebih lanjut BMT sebagai Bait at-Tamwil berfungsi sebagai salah satu perantara keuangan antara pemilik dana baik sebagai pemodal maupun penyimpanan dengan pengguna dana untuk pengembangan usaha produktif (Ridwan, 2004:131). Hal tersebut juga dilakukan oleh BMT Mu'amalah Syari'ah dengan mengadakan pembiayaan dan penyediaan modal usaha sesuai dengan prinsip syari'ah. Pembiayaan tersebut ditujukan untuk membantu pengembangan usaha bagi para pengusaha kecil yang kekurangan modal yang tidak dilayani oleh bank umum maupun bank umum syariah.

Banyak permasalahan dan kendala dalam menjalanankan usaha kecil itu sendiri. Salah satunya adalah tidak jauh dari permodalan, yang mana modal menjadi salah satu pokok utama dalam menjalankan usahanya dan diharapkan mampu untuk mengembangkan usaha tersebut. Hal ini dipertegas oleh Primiana dalam Nurika (2014), menerangkan permasalahan utama yang dihadapi UMKM saat ini disamping masalah produksi, pemasaran, jaringan kerja dan teknologi yaitu mengenai masalah akses modal dan kesempatan mendapat peluang usaha.

Adanya lembaga keuangan mikro syariah yang mampu menyediakan pembiayaan mampu sebagai alternatif dalam memperoleh modal bagi pengusaha kecil. Namun masyarakat mempunyai asumsi bahwa lembaga keuangan mikro syariah untuk masalah administrasi terlalu bertele-tele serta menganggap bahwa biaya di lembaga keuangan mikro syariah lebih mahal dibandingkan dengan lembaga keuangan konvensiaonal. Hal tersebut membuat masyarakat ragu untuk melakukan transaksi di lembaga keuangan mikro syariah.

Adanya pedagang di area kawasan wisata religi di Tebuireng dan masyarakat sekitar Tebuireng yang agamis menjadi potensi nasabah bagi BMT Mu'amalah Syari'ah Tebuireng Jombang, sehingga dapat dipastikan bahwa BMT ini telah mendapatkan kepercayaan penuh dari masyarakat Tebuirang sebagai lembaga keuangan mikro syariah yang profesional. BMT ini sudah berdiri sejak tahun 2006 dan merupakan salah satu unit bisnis dari Universitas Hasyim Asy'ari, sehingga BMT ini lebih berorientasi edukasi dan literasi keuangan syariah dibanding profit oriented.

Dari uraian di atas, peneliti tertarik untuk mengetahui pengaruh pembiayaan murabahah dan mudharabah bagi nasabah BMT Mu'amalah Syari'ah terhadap perkembangan usaha kecilnyadi kawasan Tebuireng. Kata "pembiayaan" sering digunakan untuk menunjukkan aktivitas utama BMT, karena berhubungan dengan rencana memperoleh pendanaan.

Berdasarkan UU no. 7 tahun 1992 yang dimaksud pembiayaan adalah penyediaan uang atau tagihan atau yang dapat dipersamakan dengan itu berdasarkan tujuan atau kesepakatan pinjam meminjam antara bank dengan pihak lain yang mewajibkan pihak peminjam untuk melunasi hutangnya setelah jangka waktu tertentu ditambah dengan sejumlah pembagian hasil. Sedangkan istilah Murabahah adalah akad jual beli antara bank selaku penyedia barang, dan nasabah yang memesan untuk membeli barang dagang. Bank memperoleh keuntungan yang disepakati bersama (Susanto dan Umam 2013:181).

\section{B. KAJIAN PUSTAKA}

Istilah Mudharabah dapat diartikan sebagai suatu perkongsian antara dua pihak dimana pihak pertama (shahib al-mal) menyediakan dana, dan pihak kedua (mudharib) bertanggungjawab atas pengolaan usaha (Muhammad, 2008:13). Sementara Usaha Kecil didefinisikan sebagai perorangan atau badan usaha yang telah melakukan kegiatan usaha dengan omzet per tahun setinggi-tingginya Rp. 600 juta. (Amalia, 2009). 
Baitul Maal wa Tamwil merupakan organisasi bisnis yang juga berperan sosial. Peran sosial BMT akan terlihat pada definisi baitul maal, sedangkan peran bisnis BMT terlihat dari definisi baitul tamwil. Sebagai lembaga sosial, baitul maal memiliki kesamaan fungsi dan peran dengan Lembaga Amil Zakat (LAZ), oleh karenanya, baitul maal ini harus didorong agar mampu berperan secara profesional menjadi LAZ yang mapan. Fungsi tersebut paling tidak meliputi upaya pengumpulan dana zakat, infaq, sedekah, wakaf dan sumber dana-dana sosial yang lain, dan upaya pensyarufan zakat kepada golongan yang paling berhak sesuai dengan ketentuan nasabah (Ridwan, 2004:126).

\section{METODE PENELITIAN}

Penelitian ini bersifat kuantitatif dan termasuk jenis penelitian lapangan. Pendekatan penelitian analisis kuantitatif ini dilakukan dengan menyebarkan angket atau kuesioner. Sedangkan data-data yang akan digunakan dalam penelitian ini meliputi data primer dan data sekunder.

Lokasi penelitian ini adalah BMT Mu'amalah Syari'ah yang berada di Jl. Gerilya No. 65 Komplek Simpang Lima Tebuireng Cukir Diwek Jombang. BMT Mu'amalah Syari'ah ini merupakan lembaga keuangan mikro syariah yang berfungsi sebagai penghimpun dana dari anggota, menyalurkan pembiayaan, serta mengawasi dan membina anggota dan memberikan jasa pelayanan sistem pembayaran.

Populasi dalam penelitian ini berjumlah 30 nasabah pembiayaan murabahah,sedangkan populasi untuk pembiayaan mudharabah berjumlah 19 nasabah BMT Mu'amalah Syari'ah pada tahun 2016. Untuk menentukan jumlah sampel dalam penelitian ini menggunakan sampling jenuh. Sampling jenuh adalah teknik penentuan sampel bila semua anggota populasi digunakan sebagai sampel. Hal ini sering dilakukan bila jumlah populasi relatif kecil, kurang dari 30. Istilah lain sampel jenuh adalah sensus, dimana semua anggota populasi dijadikan sampel (Sugiyono, 2015).

\section{HASIL DAN PEMBAHASAN}

Analisis regresi linier sederhana digunakan untuk memprediksi atau menguji pengaruh satu variabel bebas atau variabel independen terhadap variabel terikat aratu variabel dependen (Sahany,2015). Analisis ini digunakan untuk mengetahui seberapa besar pengaruh variabel pembiayaan murabahah $\left(X_{1}\right)$ terhadap perkembangan usaha kecil nasabah BMT Mu'amalah Syari'ah $\left(Y_{1}\right)$ dan seberapa besar pengaruh variabel pembiayaan mudharabah $\left(\mathrm{X}_{2}\right)$ terhadap perkembangan usaha kecil nasabah BMT Mu'amalah Syari'ah $\left(Y_{2}\right)$.

Analisis regresi linier sederhana terdiri dari satu variabel bebas dan satu variabel terikat, dengan persamaan :

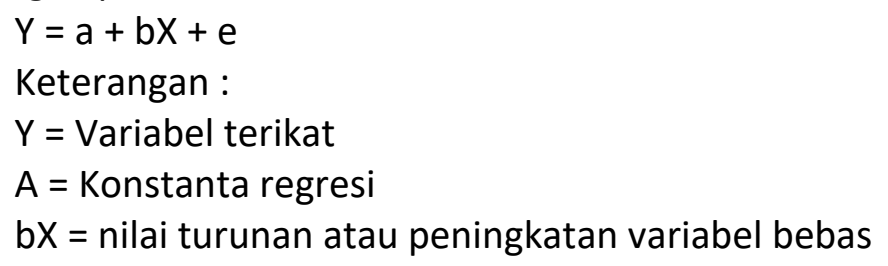

Hasil Uji Regresi Linear Sederhana Murabahah

Coefficients $^{\mathrm{a}}$

\begin{tabular}{|c|r|r|r|r|r|}
\hline Model & $\begin{array}{r}\text { Unstandardiz } \\
\text { ed Coefficients }\end{array}$ & $\begin{array}{c}\text { zed } \\
\text { Coefficients }\end{array}$ & T & ig. & $\begin{array}{c}\text { Collinearity } \\
\text { Statistics }\end{array}$ \\
\hline
\end{tabular}




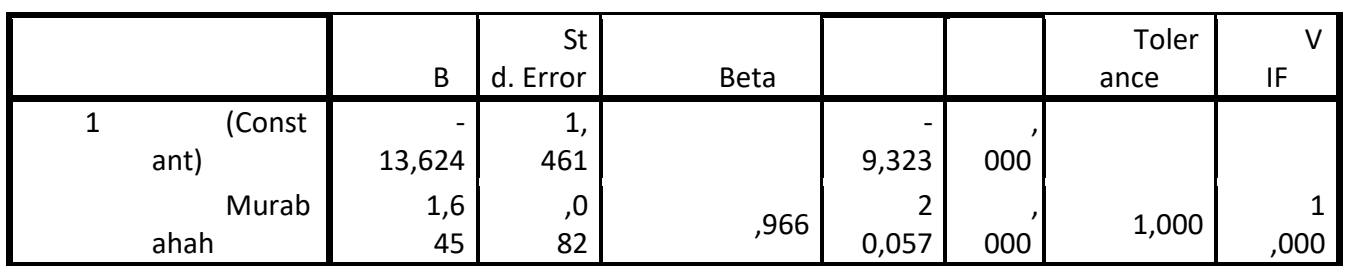

a. Dependent Variable: usaha_kecil

\section{Sumber: SPSS versi 23}

a. Berdasarkan nilai konstanta pada tabel di atas menunjukkan sebesar $-13,624$ hal tersebut menyatakan bahwa jika tidak ada pembiayaan murabahah maka tingkat perkembangan usaha kecil sebesar -13.624 .

b. Kemudian hasil dari pembiayaan murabahah adalah sebesar 1,645 hal ini menunjukkan bahwa jika pembiayaan murabahah meningkat maka perkembangan usaha kecil nasabah akan mengalami peningkatan sebesar 1,645. sebaliknya, jika pembiayaan murabahahmenurun maka perkembangan usaha kecil nasabah juga diperediksi mengalami penurunan sebesar 1,645.

\section{Hasil Uji Regresi Linear Sederhana Mudharabah}

\begin{tabular}{|c|c|c|c|c|c|c|c|}
\hline \multicolumn{8}{|c|}{ Coefficients $^{\mathrm{a}}$} \\
\hline \multirow[b]{2}{*}{ Model } & \multicolumn{2}{|c|}{$\begin{array}{l}\text { Unstandardized } \\
\text { Coefficients }\end{array}$} & \multirow{2}{*}{$\begin{array}{c}\begin{array}{c}\text { Standardi } \\
\text { zed } \\
\text { Coefficients }\end{array} \\
\text { Beta }\end{array}$} & \multirow[b]{2}{*}{$\mathrm{T}$} & \multirow[b]{2}{*}{ ig. } & \multicolumn{2}{|c|}{$\begin{array}{l}\text { Collinearity } \\
\text { Statistics }\end{array}$} \\
\hline & B & $\begin{array}{l}\text { Std. } \\
\text { Error }\end{array}$ & & & & $\begin{array}{l}\text { Toler } \\
\text { ance }\end{array}$ & $\mathrm{IF}^{\mathrm{V}}$ \\
\hline ) (Constant & $\begin{array}{r}38,89 \\
1\end{array}$ & 3,316 & & $\begin{array}{r}1 \\
1,729\end{array}$ & $000^{\prime}$ & & \\
\hline $\begin{array}{l}\text { Mudhar } \\
\text { abah }\end{array}$ & $\begin{array}{r}- \\
1,326\end{array}$ & , 190 &,- 861 & 6,983 & $000^{\prime}$ & 1,000 & $\begin{array}{r}1 \\
, 000\end{array}$ \\
\hline
\end{tabular}

a. Dependent Variable: usaha_kecil

Sumber : SPSS versi 23

c. Berdasarkan nilai konstanta pada tabel di atas menunjukkan sebesar 38,891 , menyatakan bahwa jika tidak ada pembiayaan mudharabah maka tingkat perkembangan usaha kecil sebesar 38,891.

d. Kemudian hasil dari pembiayaan mudharabah adalah -1,326 hal ini menunjukkan bahwa jika pembiayaan mudharabah meningkat maka perkembangan usaha kecil nasabah BMT Mu'amalah Syari'ah akan mengalami penurunan sebesar -1,326. sebaliknya, jika pembiayaan mudharabahmenurun maka perkembangan usaha kecil nasabah BMT Mu'amalah Syari'ah juga diperediksi mengalami peningkatan sebesar 1,326 .

Uji Normalitas Pembiayaan Murabahah

\section{One-Sample Kolmogorov-Smirnov Test}

\begin{tabular}{|c|c|c|}
\hline & & $\begin{array}{l}\text { Unstand } \\
\text { ardized } \\
\text { Residual }\end{array}$ \\
\hline \multirow{4}{*}{$\begin{array}{r}\text { Normal } \\
\text { Parameters }\end{array}$} & & 31 \\
\hline & Mean & ,000000 \\
\hline & & 0 \\
\hline & Std. & 1,98348 \\
\hline \multirow{3}{*}{$\begin{array}{l}\text { Most Extreme } \\
\text { Differences }\end{array}$} & Deviation & 819 \\
\hline & Absolut & 070 \\
\hline & Positive & 070 \\
\hline
\end{tabular}




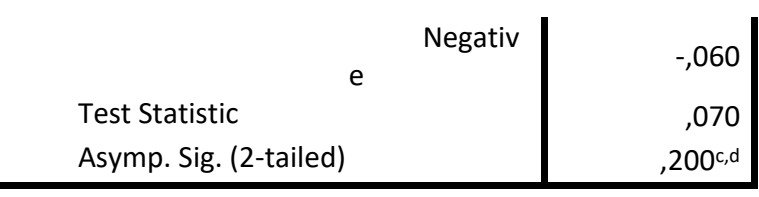

Sumber : SPSS Versi 23

e. Hasil dari uji normalitas pembiayaan murabahahadalahsebesar 0.200 hal ini menunjukkan bahwa residual berdistribusi normal, karena nilai signifikan yang dihasilkan lebih besar dari 0,05 maka $\mathrm{H}_{0}$ diterima sehingga dapat disimpulkan bahwa residual berdistribusi normal.

\section{Uji Normalitas Pembiayaan Mudharabah}

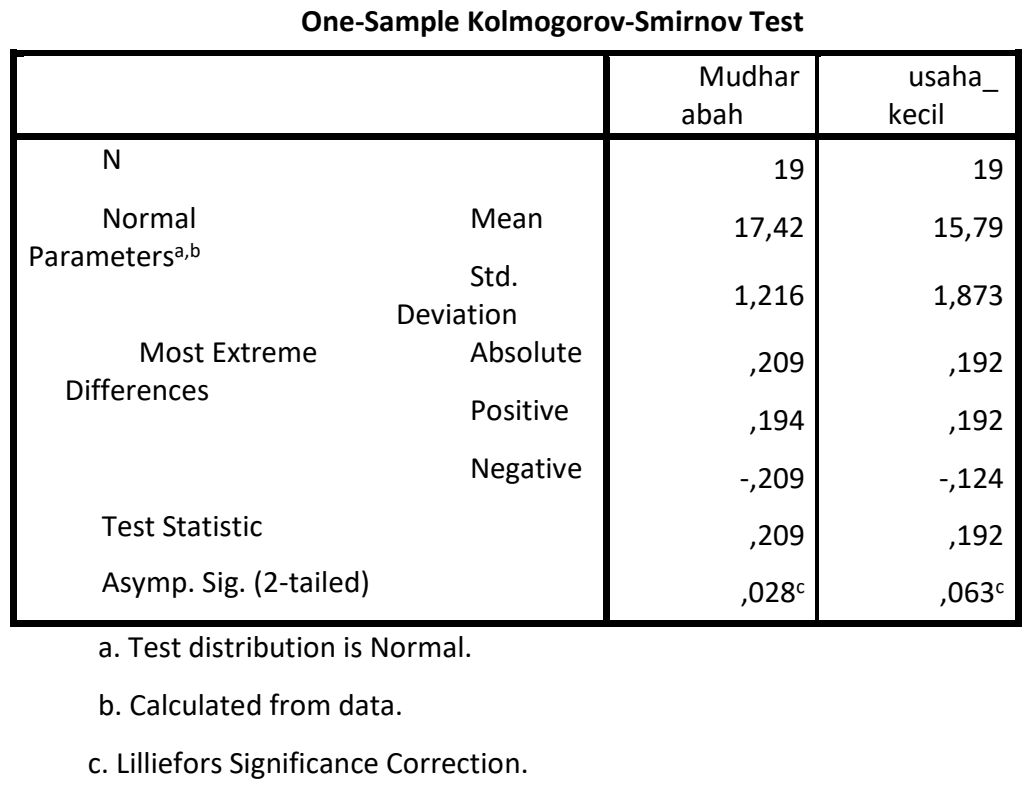

Sumber : SPSS Versi 23

f. Uji normalitas pembiayaan mudharabahmenunjukkan sebesar 0.063 hal ini bahwa residual berdistribusi normal, karena nilai signifikan yang dihasilkan lebih besar dari 0,05 maka $\mathrm{H}_{0}$ diterima sehingga dapat disimpulkan bahwa residual berdistribusi normal.

\section{Uji Heteroskedasitas pembiayaan Murabahah}

\begin{tabular}{|c|c|c|c|c|c|c|}
\hline & & \multicolumn{5}{|c|}{ Coefficients $^{a}$} \\
\hline \multirow[b]{2}{*}{ Model } & & \multicolumn{2}{|c|}{$\begin{array}{l}\text { Unstandardize } \\
\text { d Coefficients }\end{array}$} & \multirow{2}{*}{$\begin{array}{c}\begin{array}{c}\text { Standardi } \\
\text { zed } \\
\text { Coefficients }\end{array} \\
\text { Beta }\end{array}$} & \multirow[b]{2}{*}{$\mathrm{T}$} & \multirow[b]{2}{*}{ g. ${ }^{\text {Si }}$} \\
\hline & & B & $\begin{array}{l}\text { Std. } \\
\text { Error }\end{array}$ & & & \\
\hline $\begin{array}{ll}1 & \\
& t)\end{array}$ & (Constan & 657 & 1,567 & & $\begin{array}{r}, 4 \\
19\end{array}$ & $\begin{array}{l}, 6 \\
78\end{array}$ \\
\hline hah & Muraba & $\begin{array}{r}- \\
, 165\end{array}$ & ,134 &,- 374 & $\begin{array}{r}- \\
1,229\end{array}$ & $\begin{array}{l}, 2 \\
29\end{array}$ \\
\hline ecil & usaha_k & $146^{\prime}$ & ,079 & ,563 & $\begin{array}{r}1 \\
850\end{array}$ & $\begin{array}{l}, 0 \\
75\end{array}$ \\
\hline
\end{tabular}

a. Dependent Variable: Unstandardized Residual

Sumber : SPSS versi 23

g. Pembiayaan murabahah menunjukkan bahwa tidak terjadi masalah heteroskedastisitas. Hal ini karena nilai signifikansi semuanya melebihi 0,05. Hasil 
yang ditunjukkan oleh tabel tersebut menunjukkan 0,229 artinya tidak terjadi masalah heteroskedastisitas.

Uji Heteroskedasitas Pembiayaan Mudharabah

Sumber : Spss versi 23

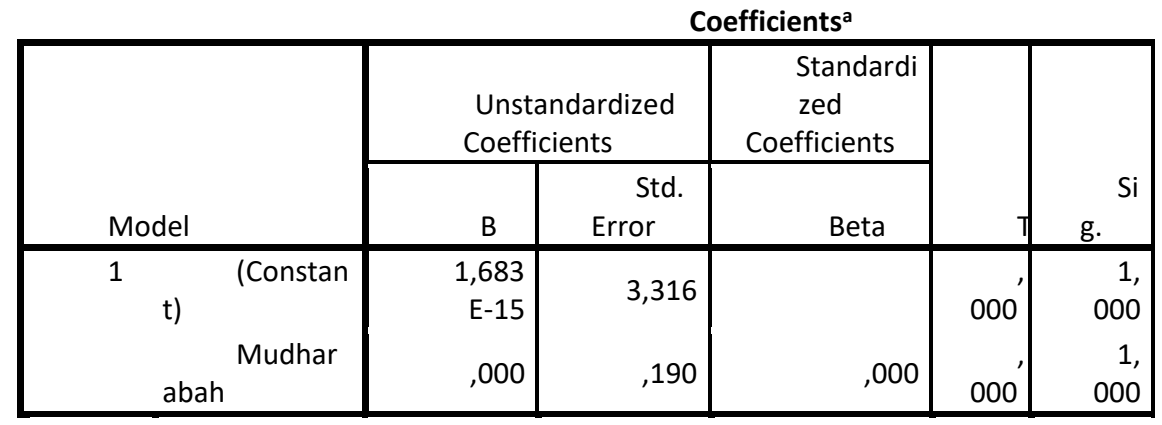

a. Dependent Variable: Unstandardized Residual

h. Pembiayaan mudharabahmenunjukkan bahwa tidak terjadi masalah heteroskedastisitas. Hal ini karena nilai signifikansi semuanya melebihi 0,05. Hasil yang ditunjukkan oleh tabel tersebut menunjukkan 1,000 artinya tidak terjadi masalah heteroskedastisitas.

Sumber : SPSS versi 23

\section{Uji Parsial (T) Pembiayaan Murabahah}

Coefficients $^{\mathrm{a}}$

\begin{tabular}{|c|c|c|c|c|c|c|c|}
\hline \multirow[b]{2}{*}{ Model } & \multicolumn{2}{|c|}{$\begin{array}{l}\text { Unstandardized } \\
\text { Coefficients }\end{array}$} & \multirow{2}{*}{$\begin{array}{c}\begin{array}{c}\text { Standardi } \\
\text { zed } \\
\text { Coefficients }\end{array} \\
\text { Beta }\end{array}$} & \multirow[b]{2}{*}{$T$} & \multirow[b]{2}{*}{ g. $\mathrm{Si}$} & \multicolumn{2}{|c|}{$\begin{array}{l}\text { Collinearity } \\
\text { Statistics }\end{array}$} \\
\hline & B & $\begin{array}{l}\text { Std. } \\
\text { Error }\end{array}$ & & & & $\begin{array}{l}\text { Toleran } \\
\text { ce }\end{array}$ & $\mathrm{IF}^{\mathrm{V}}$ \\
\hline $\begin{array}{ll} & \text { (Const } \\
\text { ant) } & \end{array}$ & 13,624 & 1,461 & & 9,323 & $\begin{array}{l}, 0 \\
00\end{array}$ & & \\
\hline ahah Murab & 1,645 & ,082 & 966 & $\begin{array}{r}2 \\
0,057\end{array}$ & $\begin{array}{l}, 0 \\
00\end{array}$ & 1,000 & $\begin{array}{r}1 \\
, 000\end{array}$ \\
\hline
\end{tabular}

a. Dependent Variable: usaha_kecil

i. Nilai signifikansi Pembiayaan Murabahah lebih kecil dari 0,05 yaitu sebesar 0,000 hal ini menunjukkan bahwa pembiayaan Murabahah mempunyai pengaruh yang signifikan terhadap perkembangan usaha kecil nasabah BMT Mu'amalah Syari'ah.

\section{Uji Parsial (T) Pembiayaan Mudharabah}

Coefficients $^{a}$

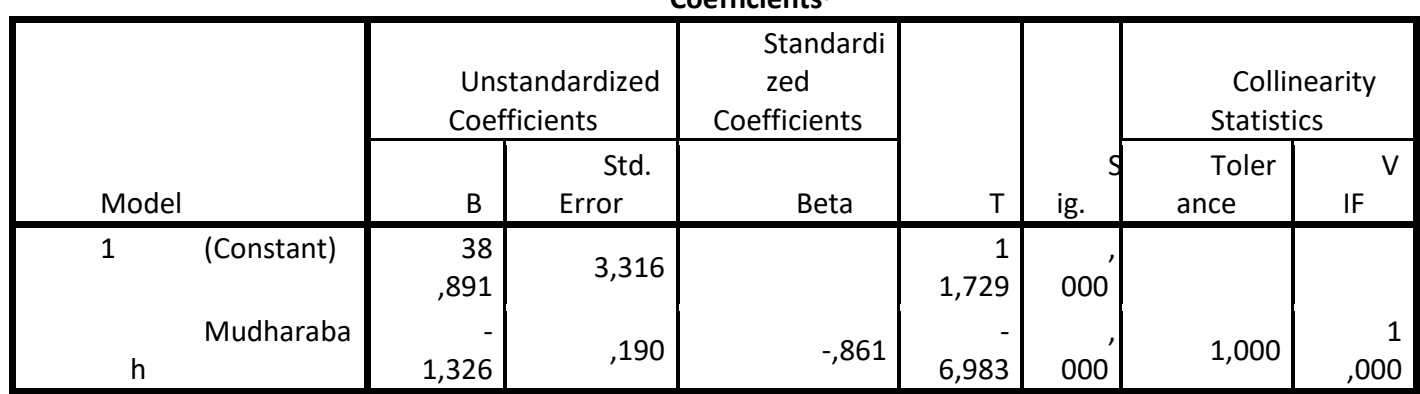

a. Dependent Variable: usaha_kecil

Sumber : SPSS Versi 23

j. Nilai signifikansi Pembiayaan Mudharabah lebih kecil dari 0,05 yaitu 0,000 hal ini menunjukkan bahwa pembiayaan Mudharabah mempunyai pengaruh yang signifikan terhadap perkembangan usaha kecil nasabah BMT Mu'amalah Syari'ah. 
Berdasarkan hasil dari penelitian ini maka analisis data yang telah diolah menggunakan software SPSS 23.0 adalah sebagai berikut:

1. Pengaruh Pembiayaan Murabahahterhadap Perkembangan Usaha Kecil

Dapat diketahui dari hasil uji hipotesis melalui uji $\mathrm{t}$ bahwa pembiayaan murabahahmempunyai pengaruh terhadap perkembangan usaha kecil. Hal tersebut dijelaskan dengan hasil yang ditunjukkan oleh nilai signifikasi pembiayaan murabahahyakni 0,000, yang mana nilai signifikasi tersebut lebih kecil dari 0,05. Disamping itu dilihat dari analisis regresi sederhana nilai pembiayaan murabahahsebesar konstanta $-13,624$, menyatakan bahwa jika tidak ada pembiayaan murabahah maka tingkat perkembangan usaha kecil sebesar -13,624. Hal ini berarti jika pembiayaan murabahahmeningkat maka perkembangan usaha kecil nasabah BMT Mu'amalah Syari'ah juga ikut meningkat sebesar 1,645. Dan sebaliknya, jika pembiayaan murabahahmenurun maka perkembangan usaha kecil nasabah BMT Mu'amalah Syari'ah juga diprediksi mengalami penurunan sebesar 1,645 .

Dapat disimpulkan bahwa dalam penelitian ini pengaruh pembiayaan murabahahmempunyai pengaruh yang positif terhadap perkembangan usaha kecil. Karena pembiayaan murabahah mampu meningkatkan perkembangan usaha kecil sehingga dapat menguntungkan bagi para nasabah usaha kecil yang kekurangan permodalan. Dengan demikian variabel pembiayaan murabahahdapat dijadikan alat untuk meningkatkan perkembangan usaha kecil nasabah BMT Mu'amalah Syari'ah.

Pada dasarnya BMT Mu'amlaah Syari'ah ini mempunyai maksud dan tujuan untuk mengadakan pembiayaan dan penyediaan model usaha dengan sistem syari'ah. Pembiayaan tersebut dilakukan untuk membantu para pengusaha kecil yang kekurangan modal. Dengan memberikan pembiayaan murabahahini nasabah bisa mengembangkan usaha-usahanya. Pembiayaan murabahah sendiri yakni penyediaan barang oleh BMT yang mana pihak pembeli harus mengembalikan sejumlah pokok ditambah keuntungan tertentu yang telah disepakati ( Ridwan, 2004:180).

Sedangkan sebagai produk pembiayaan, BMT Mu'amalah Syari'ah dapat mengembangkan produk murabahahsehingga masyarakat yang ada disekitar supaya bisa lebih mengetahui bagaimana manfaat dari produk murabahahtersebut. Karena masih banyak masyarakat yang belum faham mengenai produk murabahahsehingga masyarakat yang kekurangan modal belum menjadi anggota dari BMT Mu'amalah Syari'ah.

Disisi lain produk yang dipilih oleh nasabah BMT Mu'amlah Syari'ah kebanyakan pembiayaan murabahahyang bersifat konsumtif, oleh karena itu dengan adanya pengembangan produk dan sosialisasi diharapkan banyak nasabah yang memilih produk pembiayaan produktif. Karena pembiaayan produktif ini ditujukan untuk memenuhi kebutuhan produksi dalam arti yang sangat luas seperti pemenuhan kebutuhan modal untuk meningkatkan volume penjualan dan produksi.

2. Pengaruh Pembiayaan Mudharabahterhadap Perkembangan Usaha Kecil

Dari hasil analisis regresi linier sederhana diperoleh nilai regresi pembiayaan mudharabah sebesar - 1,326 hal ini menunjukkan bahwa jika pembiayaan mudharabah meningkat maka perkembangan usaha kecil akan mengalami penurunan sebesar -1,326. Dan sebaliknya, jika pembiayaan mudharabah menurun maka perkembangan usaha kecil juga diprediksi mengalami peningkatan sebesar - 
1,326. Sedangkan hasil pengujian hipotesis menunjukkan bahwa nilai signifikansi pembiayaan mudharabah lebih kecil dari 0,05 yaitu 0,000 hal ini menunjukkan bahwa pembiayaan mudharabah mempunyai pengaruh yang positif dan signifikan terhadap perkembangan usaha kecil.

Hal tersebut didukung dengan penelitian Sahany (2015), yang menyatakan bahwa ada hubungan atau pengaruh positif antara pembiayaan mudharabah dengan perkembangan UMKM. Yang menunjukkan dari hasil uji $t$ pada pembiayaan murabahah yaitu t-hitung > t-tabel sebesar 5,194 > 2,160 sehingga variabel independen berpengaruh terhadap variabel dependen dan signifikasi bernilai 0,000 $<0,05$ sehingga $\mathrm{HO}$ ditolak dan $\mathrm{H} 1$ diterima. Sedangkan pembiayaan Mudharabah memiliki hasil uji t t-hitung sebesar 2,568 >t-tabel 2,160 dan signifikasi sebesar 0,023 $<0,05$ sehingga $\mathrm{H} 2$ ditolak dan $\mathrm{H} 3$ diterima.

Dapat disimpulkan bahwa pengaruh pembiayaan mudharabah mempunyai pengaruh positif dan signifikan terhadap perkembangan usaha kecil. Di karenakan bahwa pembiayaan Mudharabah mampu meningkatkan perkembangan usaha kecil sehingga dapat menguntungkan bagi nasabah usaha kecil.

BMT Mu'amalah Syari'ah dalam menjalankan prinsip operasionalnya yakni salah satunya dengan sistem bagi hasil, yang mana sistem ini meliputi tata cara pembagian hasil usaha, antar pemodal dengan pengelola dana. Pembagian hasil tersebut dilakukan antara BMT dengan pengelola dana, dan antara dana BMT dengan pengelola dana. Serta hasil keuntungannya akan dibagikan sesuai dengan kesepakatan bersama.

Dalam penyertaan tersebut, BMT hanya akan berperan sebagai anggota pasif, karena segala manajemen operasionalnya akan dikelola oleh mudharib. Yang termasuk dalam jenis transaksi pernyertaan modal salah satunya mudharabah. Mudharabah sendiri yakni kerja sama usaha antara pihak BMT (Shahibul maal) dengan nasabah (Mudharib) yang seluruh modalnya berasal dari BMT. Nisbah bagi hasil akan disepakati bersama kedua belah pihak (Ridwan, 2004:178). Sejauh ini produk mudharabah BMT Mu'amalah Syari'ah ini perlu dikembangkan lebih lanjut, supaya bertambah lebih banyak nasabahnya.

\section{E. KESIMPULAN}

Berdasarkan hasil penelitian di atas maka diperoleh kesimpulan sebagai berikut:

1. Pengaruh Pembiayaan Murabahahterhadap Perkembangan Usaha Kecil

Dari hasil uji hipotesis yang diuji melalui uji t menunjukkan bahwa pembiayaan murabahahmempunyai pengaruh terhadap perkembangan usaha kecil. Hal tersebut dijelaskan dengan hasil yang ditunjukkan oleh nilai signifikasi pembiayaan murabahahyakni 0,000. Jadi, dalam penelitian ini pengaruh pembiayaan murabahahmempunyai pengaruh yang positif terhadap perkembangan usaha kecil. Dengan demikian variabel pembiayaan murabahahdapat dijadikan alat untuk meningkatkan perkembangan usaha kecil. Karena pembiayaan Murabahah mampu meningkatkan perkembangan usaha kecil sehingga dapat menguntungkan bagi para nasabah usaha kecil yang kekurangan permodalan.

Sebagai produk pembiayaan, BMT Mu'amalah Syari'ah dapat mengembangkan produk murabahahsehingga masyarakat yang ada disekitar supaya bisa lebih mengetahui bagaimana manfaat dari produk murabahahtersebut. Karena masih banyak masyarakat yang belum faham mengenai produk murabahahsehingga 
masyarakat yang kekurangan modal belum menjadi anggota dari BMT Mu'amalah Syari'ah.

Disisi lain produk yang dipilih oleh nasabah BMT Mu'amlah Syari'ah kebanyakan pembiayaan murabahahyang bersifat konsumtif, oleh karena itu dengan adanya pengembangan produk dan sosialisasi diharapkan banyak nasabah yang memilih produk pembiayaan produktif.

2. Pengaruh Pembiayaan Mudharabahterhadap Perkembangan Usaha Kecil

Dari hasil analisis regresi linier sederhana diperoleh nilai regresi pembiayaan mudharabah(X2) sebesar -1,326. Nilai koefisien tersebut menunjukan bahwa apabila variabel pembiayaan mudharabahmengalami peningkatan maka perkembangan usaha kecil akan mengalami penuruanan sebesar -1,326. Sedangkan hasil pengujian hipotesis menunjukkan bahwa nilai signifikansi pembiayaan mudharabah lebih kecil dari 0,05 yaitu 0,000 hal ini menunjukkan bahwa pembiayaan mudharabah mempunyai pengaruh yang signifikan terhadap perkembangan usaha kecil.

Dapat disimpulkan bahwa pengaruh pembiayaan mudharabah mempunyai pengaruh positif dan signifikan terhadap perkembangan usaha kecil. Di karenakan bahwa pembiayaan Mudharabah mampu meningkatkan perkembangan usaha kecil sehingga dapat menguntungkan bagi nasabah usaha kecil.

BMT Mu'amalah Syari'ah dalam menjalankan prinsip operasionalnya yakni salah satunya dengan sistem bagi hasil, yang mana sistem ini meliputi tata cara pembagian hasil usaha, antar pemodal dengan pengelola dana. Pembagian hasil tersebut dilakukan antara BMT dengan pengelola dana, dan antara dana BMT dengan pengelola dana. Serta hasil keuntungannya akan dibagikan sesuai dengan kesepakatan bersama.

\section{DAFTAR PUSTAKA}

Amalia, Eulis. (2009). Keadilan Distributif Dalam Ekonomi Islam Penguatan Peran LKM dan UKM Di Indonesia. Jakarta: Rajawali Press

Antonio, Syari'i. (2001). Bank Syariah Dari Teori Ke Praktek. Jakarta : Gema Insani.

Muhammad. (2008). Sistem \& Prosedur Operasional Bank Syariah. Yogyakarta : UII Press.

Ridwan Muhammad. (2004). Manajemen Baitul Maal Wa Tamwil. Yogyakarta : UII Press

Sahany Henita, (2015). Pengaruh Pembiayaan Murabahah dan Mudharabah Terhadap Perkembangan Usaha Mikro Kecil Dan Menengah (UMKM) BMT El Syifa Ciganjur. Jakarta : Universitas Islam Negeri Syarif Hidayatullah

Sugiyono. (2015). Metode Penelitian Kombinasi (Mixed Methods). Bandung : Alfa Beta.

Umam, Khaerul dan Susanto, Herry. (2013). Manajemen Pemasaran Bank Syariah. Bandung : Pustaka Setia 